\title{
SUPPLEMENTING LIVE DRIED YEAST (Saccharomyces cerevisiae) TO DIETS VARYING IN ROUGHAGE: CONCENTRATE RATIO: \\ 1- DIGESTIBILTY COEFFICIENTS, FEEDING VALUES AND FERMENTATION IN THE RUMEN OF ZARAIBI GOAT BUCKS
}

Mehrez, A. Z.1; A. A. Gabr ${ }^{1}$; M. Y. El-Ayek ${ }^{1}$; M. E. Ahmed ${ }^{2}$ and Alaa M. Gad1

1. Anim. Prod. Dept., Fac. Of Agric., Mansoura Univ., Egypt.

2. Anim. Res. Inst., Agric. Res. Center, Min. of Agric., Egypt.

\section{ABSTRACT}

This study was conducted to investigate the effect of live dried yeast (RumiYeast, RY) (Saccharomyces cerevisiae) supplementation, which is a commercial probiotic containing yeast, on digestion coefficients, feeding values and some rumen parameters of Zaraibi goats diets at two roughage (corn silage, CS): concentrate (concentrate feed mixture, CFM) ratios (70: 30 and $30: 70 \%$ ) i.e. high roughage (HR) and high CFM (HC). Both diets were either used with RY $(3 \mathrm{~g} / \mathrm{h} / \mathrm{d})$ or without RY addition. Twelve mature Zaraibi bucks with an average live body weight of $60 \pm 0.4 \mathrm{~kg}$ were selected randomly from station herd and divided into four equal groups according to their body weight (3 bucks in each). Four experimental diets were formulated as follows: Diet 1: $70 \%$ CFM + 30\% CS with RY, Diet 2: $70 \%$ CFM + 30\% CS without RY, Diet 3: $30 \%$ CFM + 70\% CS with RY and Diet 4: $30 \%$ CFM + 70\% C\$ without RY.

The main results showed that addition of RY significantly $(p<0.05)$ enhanced all nutrients digestibility coefficients, as well as digestibility of cell wall constituents (NDF, ADF, ADL, cellulose, hemicelluloses). Live dried yeast addition improved nutritive values as total digestible nutrients (TDN) and digestible crude protein (DCP $\%$ ). Rumen parameters ( $\mathrm{pH}$ values, TVFA'S and ammonia- $\mathrm{N}$ concentrations) were improved with $\mathrm{HC}$ diets compared with $\mathrm{HR}$ ones. In conclusion, live dried yeast (RumiYeast) addition to diets of Zaraibi goats diets improved most of the tested parameters mentioned before and has a higher influence when included with HC than with HR diets under field condition.

Keywords: Zaraibi goats, live yeast culture, roughage: concentrate ratio, digestibility coefficients, rumen parameters.

\section{INTRODUCTION}

Dietary addition of Saccharomyces cerevisiae has been widely used in ruminant nutrition to manipulate rumen fermentation, feed utilization and improve animal performance. Several studies (Haddad and Goussous, $2005 a$ and Fadel Elseed and Abusamra, 2007) have shown that yeast culture and live yeast supplementation increased feed intake_(Haddad and Goussous, 2005 a\&b and. Fadel Elseed and Abusamra, 2007), (Kim et at. 2006 ) increased in some nutrients digestibility. (Miller et al., 2002 and Lilla et al., 2004) ${ }_{2}$ improved patterns of fermentation in the rumen_(Kim et al. 2006),

Formatted: Font: Not Bold, Complex Script Font: Not Bold Formatted: Font: Not Bold, Complex Script Font: Not Bold Formatted: Font: Not Bold, Complex Script Font: Not Bold Formatted: Font: Not Bold, Complex Script Font: Not Bold Formatted: Font: Not Bold, Complex Script Font: Not Bold Formatted: Font: Not Bold, Complex Script Font: Not Bold Formatted: Font: Not Bold, Complex Script Font: Not Bold Formatted: Font: Not Bold, Complex Script Font: Not Bold 
increased digestibility of some nutrients, (Miller et al., 2002 and Lila et al., 2004), enhancement of the activity of different ruminal bacteria (Dolezal et al., 2005), increased in-concentration of VFA $A_{i}$ especially (Nursoy and Baytok, 2003), increased-acetic acid and decreased the ruminal ammonia production (Nursoy and Baytok, 2003). However, performance results of ruminants fed yeast culture and live yeast have been multiple due to many factors such as differences in strain, yeast dose, the viability of yeast cells, diet composition, forage to concentrate ratio, type of forage fed, feeding strategy, the physiological status of the animal and stage of lactation (Maseki et al., 2008; Chaucheyras-Durand et al., 2008; Inal et al., 2010 and Yalçın et. al., 2011).

Rumi yeast (RY) comprises of a very large amount of commercial living yeast cells of Saccharomyces cerevisiae with a huge fermentative capacity, mixed with buffer and palatability factors. The RY is characterized by stabilizing rumen $\mathrm{pH}$ and oxygen consumption, stimulation of fiber digestion and stimulation of development of the rumen microflora.

The ratio of roughage to concentrates is one of the major dietary important factors in diet formulation. It influences feed intake which is reflected on rumen digesta kinetics and consequently rumen environment.

This study was designed to investigate the effect of adding Rumi yeast (RY) in Zaraibi goat's diets at two roughage: concentrate ratios on nutrient digestibilities, feeding values and some rumen parameters.

\section{MATERIALS AND METHODS}

The experimental work of this study was carried out at El-Serw Experimental Station, Animal Production Research Institute, Agriculture Research Center and Animal Production Department, Faculty of Agriculture, Mansoura University. Two diets containing two ratios (30: 70) and (70: 30) of roughage (corn silage, CS) and concentrate (concentrate feed mixture, CFM) i.e. high roughage $(\mathrm{HR})$ and high CFM $(\mathrm{HC})$, respectively with or without Rumi-Yeast (RY) addition were evaluated. The level of $3 \mathrm{~g} R Y /$ head/day was chosen as recommended dose suggested by the producing company (Multi Vita, Egypt) for small dairy ruminants rations, since this level was economical in feeding practices. The tested diets were formulated as follows: Diet 1: $70 \%$ $\mathrm{CFM}+30 \% \mathrm{CS}$ with RY (HC), Diet 2: $70 \% \mathrm{CFM}+30 \% \mathrm{CS}$ without RY (HC), Diet 3: 30\% CFM + 70\% CS with RY (HR) and Diet 4: $30 \% \mathrm{CFM}+70 \% \mathrm{CS}$ without $\mathrm{RY}(\mathrm{HR})$.i.e $2 \times 2$ factorial design. The composition and the chemical analysis of the ingredients and tested diets are shown in Tables 1 and 2 . The amount of yeast culture was mixed with the mash portion of CFM prior to feeding which was completely consumed. Goats were fed according to NRC (1981) recommendations. Average daily total dry matter intake was 920 (632 $\mathrm{CFM}+288 \mathrm{CS} \mathrm{g} / \mathrm{head})$ and 937 (262 CFM + 675 CS g / head) for HC and $\mathrm{HR}$ diets, respectively which was very closed to the planned ratios and the level of feeding was kept constant either with or without RY supplemented diets. The animals were fed the four respective diets in two meals/day (8 a.m. and 3 p.m.). Fresh water was available all time.
Formatted: Font: Not Bold, Complex Script Font: Not Bold Formatted: Font: Not Bold, Complex Script Font: Not Bold Formatted: Font: Not Bold, Complex Script Font: Not Bold

Formatted: Font: Not Bold, Complex Script Font: Not Bold

Formatted: Font: Not Bold, Complex Script Font: Not Bold

Formatted: Font: Not Bold, Complex Script Font: Not Bold

Formatted: Font: Not Bold, Complex Script Font: Not Bold

Formatted: Font: Not Bold, Complex Script Font: Not Bold

Formatted: Font: Not Bold, Complex Script Font: Not Bold 
Four digestion trials were carried out to determine the digestibility coefficients and feeding values of the tested diets. Twelve mature Zaraibi bucks with an average live body weight of $60 \pm 0.4 \mathrm{~kg}$ were divided into four groups, ( 3 bucks each). The animals of each group were kept in a separate shaded pen. Digestion coefficients of the tested diets were determined using acid insoluble ash (AIA) technique according to Van Keulen and Young (1977). Fecal samples were collected from the rectum twice daily for 10 days from all groups. Feces samples (10\% of fresh feces) of each buck were mixed well and kept in the refrigerator for chemical analysis. Samples of feed and feces were analyzed for CP, CF, EE and ash according to A.O.A.C. (1995). Fiber fractions, neutral detergent fiber (NDF), acid detergent fiber $r$ (ADF) and acid detergent lignin (ADL), were determined according to Vah Soest (1981). Hemicellulose and cellulose were calculated by the differences between NDF and ADF, and between ADF and ADL, respectively. The gross energy of the tested diets was calculated according to MAFF (1975) equation:

$\mathrm{GE}(\mathrm{MJ} / \mathrm{kg} \mathrm{DM})=0.0226 \mathrm{CP}+0.0407 \mathrm{EE}+0.0192 \mathrm{CF}+0.0177 \mathrm{NFE}$ Where: CP, EE, CF and NFE were expressed as $\mathrm{g} / \mathrm{kg} \mathrm{DM}$.

At the end of the trials, rumen fluid samples were taken from all bucks of each group at two consecutive days using stomach tube before feeding and at 3 and 6 hrs post-feeding. The rumen samples were filtered through 3 layers of gauze. The Ruminal $\mathrm{pH}$ values were measured immediately by portable battery operated $\mathrm{pH}$ meter (Orion Research, model 201/digital pH meter). Ruminal ammonia nitrogen $\left(\mathrm{NH}_{3}-\mathrm{N}\right)$ concentration was measured according to Conway and O'Malley (1957). Total VFA's concentration was determined by the steam distillation method according to Abou-Akkada and El-Shazly (1964). Fresh drinking water was available at all times.

Collected data of nutrients digestibilities and feeding values were subjected to statistical analysis using two-way analysis of variance (2Xp factorial) according to (SAS 2004) using the following mathematical model:

$Y_{i j k}=\mu+P_{i}+S_{j}+P S_{i j}+e_{i j k}$

Where $Y_{i j k}=$ observed traits, $\mu=$ overall mean, $P_{i}=$ experimental diet $1-4(1=$ $\operatorname{diet} 1,2=\operatorname{diet} 2,3=\operatorname{diet} 3,4=\operatorname{diet} 4), S_{j}=$ supplement (supplemented with and supplemented without), $P S_{i j}=$ interaction treatment $x$ supplement, $\mathrm{e}_{\mathrm{ijk}}=$ Random error.

The data of rumen parameters were subjected to $2 \times 2 \times 3$ factorial analysis of variance according to the following model:

$Y_{i j k}=\mu+P_{i}+S_{j}+T_{k}+P S_{i j}+P T_{i k}+S T_{j k}+P S T_{i j k}+e_{i j k}$

Where $Y_{i j k}=$ observed traits, $\mu=$ overall mean, $P_{i}=$ experimental diet $1-4(1=$ $\operatorname{diet} 1,2=\operatorname{diet} 2,3=\operatorname{diet} 3,4=\operatorname{diet} 4), S_{j}=$ supplement (supplemented with and supplemented without), $T_{k}=$ time of sampling, $P S_{i j}=$ interaction treatment $x$ supplement, $\mathrm{PT}_{\mathrm{ik}}=$ interaction treatment $\times$ time, $\mathrm{ST}_{\mathrm{JK}}=$ interaction supplement $\times$ time, $\mathrm{PST}_{\mathrm{ijk}}=$ interaction treatment $\times$ supplement $\times$ time and $\mathrm{e}_{\mathrm{ijk}}=$ Random error.

Means were compared according to Duncan's Multiple Range Test at 0.05 level (Duncan, 1955).

\section{RESULTS AND DISCUSSION}

Formatted: Font: Not Bold, Complex Script Font: Not Bold

Formatted: Font: Not Bold, Complex Script Font: Not Bold

Formatted: Font: Not Bold, Complex Script Font: Not Bold

Formatted: Font: Not Bold, Complex Script Font: Not Bold

Formatted: Font: Not Bold, Complex Script Font: Not Bold

Formatted: Font: Not Bold, Complex Script Font: Not Bold

Formatted: Font: Not Bold, Complex Script Font: Not Bold

Formatted: Font: Not Bold, Complex Script Font: Not Bold

Formatted: Font: Not Bold, Complex Script Font: Not Bold

Formatted: Font: Not Bold, Complex Script Font: Not Bold

Formatted: Font: Not Bold, Complex Script Font: Not Bold

Formatted: Font: Not Bold, Complex Script Font: Not Bold

Formatted: Font: Not Bold, Complex Script Font: Not Bold 


\section{Chemical composition of experimental diets:}

Chemical composition of the feedstuffs and the calculated chemical composition of the experimental diets are presented in Tables 1 and 2 . Values of nutrient contents of tested corn silage (CS) were nearly similar to those obtained by El-Ashry et al. (2003) and Aboul-Fotouh et al. (2011). In addition, Abou Ammou et al. (2011) and El-Badawi et al. (2011) reported similar composition for concentrate feed mixture (CFM). The calculated chemical composition of formulated diets showed that HR diet and $\mathrm{HC}$ diet are nearly similar in $\mathrm{OM}, \mathrm{EE}$, ash contents and gross energy concentration. However, HC diet had higher DM and CP than HR diet by about 41.41 and $17.19 \%$, respectively. In contrary, CF content of HR diet was practically higher than that of $\mathrm{HC}$ diet by about $27.51 \%$. Also, combining these two ingredients in formulating the two experimental diets decreased NDF, ADF and cellulose contents with $\mathrm{HC}$ diet compared to the HR one (Table 2) as a result of increasing CS or decreasing CFM proportions in tested diets.

Table 1. Proximate analysis (\%) of the feed ingredients used in formulating the tested diets.

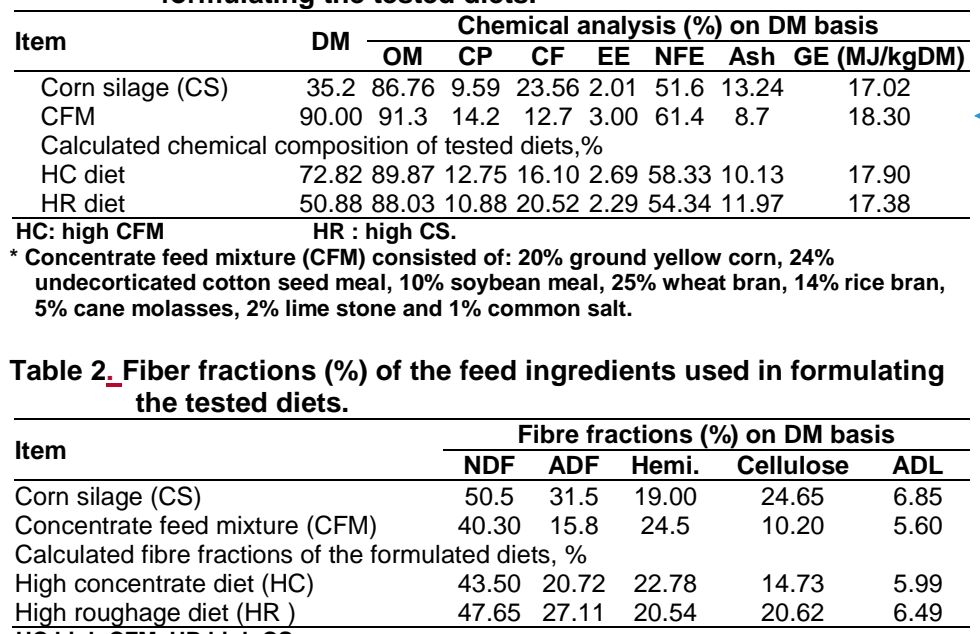

HC high CFM, HR high CS

Effect of C:R ratio and $R Y$ supplementation (RYS) on nutrients digestibility and feeding values:

As shown in Tables 3 and $4_{1}$ the digestibility coefficients of all nutrients, NDF, ADF, ADL, cellulose and hemicellulose of $\mathrm{HC}$ diet digestibility-were significantly $(\mathrm{P}<0.05)$ higher than the coefficient_HR diet. These results agreed with those obtained by Fouad (2001) with cows and Mehrez et al. (2001) and Al-Dabeeb and Ahmed (2002) with sheep.
Formatted: Font: Not Bold, Complex Script Font: Not Bold Formatted: Font: Not Bold, Complex Script Font: Not Bold Formatted: Font: Not Bold, Complex Script Font: Not Bold Formatted: Font: Not Bold, Complex Script Font: Not Bold

Formatted: Font: 10 pt, Not Bold, Complex Script Font: 10 pt, Not Bold

\section{Formatted Table}

Formatted: Font: Not Bold, Complex Script Font: Not Bold Formatted: Font: Not Bold, Complex Script Font: Not Bold Formatted: Font: Not Bold, Complex Script Font: Not Bold Formatted: Font: Not Bold, Complex Script Font: Not Bold 
The same trend was observed for TDN and DCP\% values, it was clear that the as a reflection of the increase in digestibility coefficients. Addition of high level of CFM caused an increase $(P<0.05)$ in TDN and DCP values compared with the lower level, being 68.24 and $9.90 \%$ and 66.19 and $9.58 \%$, respectively for $\mathrm{HC}$ and $\mathrm{HR}$ diet, respectively. These results are in agreement with those obtained by Mehrez et al. (2001) and Fouad (2001) who found that the improvement in the nutritive values of the high CFM diet was associated with higher nutrients digestibility coefficients compared with HR one.

Table 3. Mean effect of $\mathrm{R}: \mathrm{C}$ ratio and $\mathrm{RY}$ supplementation on digestion coefficients and feeding values of the tested diets.

\begin{tabular}{|c|c|c|c|c|c|c|}
\hline \multirow{2}{*}{ Item } & \multicolumn{3}{|c|}{ C:R ratio } & \multicolumn{3}{|c|}{ RY supplementation } \\
\hline & $\mathrm{HC}$ & HR & $\pm \mathrm{SE}$ & + & - & $\pm \mathrm{SE}$ \\
\hline \multicolumn{7}{|c|}{ Digestibility coefficients $\%$} \\
\hline DM & 72.93 & 71.98 & 0.39 & 73.05 & 71.87 & 0.39 \\
\hline OM & $74.90^{\mathrm{a}}$ & $73.43^{b}$ & 0.32 & $74.80^{\mathrm{a}}$ & $73.53^{b}$ & 0.31 \\
\hline $\mathrm{CP}$ & $76.53^{a}$ & $73.12^{b}$ & 0.38 & $75.88^{a}$ & $73.77^{b}$ & 0.38 \\
\hline CF & $66.33^{a}$ & $63.28^{b}$ & 0.26 & $65.77^{\mathrm{a}}$ & $63.85 \mathrm{~b}$ & 0.26 \\
\hline EE & $80.33^{a}$ & $76.32^{b}$ & 0.41 & $79.48^{a}$ & $77.17^{b}$ & 0.41 \\
\hline NFE & $71.88^{a}$ & $68.65^{\mathrm{b}}$ & 0.30 & $71.22^{a}$ & $69.32^{b}$ & 0.30 \\
\hline \multicolumn{7}{|c|}{ Nutritive values (on DM basis ) } \\
\hline TDN\% & $67.23^{a}$ & $61.99^{b}$ & 0.15 & $65.52^{a}$ & $63.70^{b}$ & 0.15 \\
\hline DCP\% & $9.75^{a}$ & $7.95^{\mathrm{b}}$ & 0.04 & $8.98^{a}$ & $8.73^{b}$ & 0.04 \\
\hline
\end{tabular}

$a$ and ${ }^{b}$, means in the same row with different superscripts differ significantly $(P<0.05)$.

Table 4. Mean effect of R:C ratio and RY supplementation on digestion coefficients of the fiber fractions of the tested diets.

\begin{tabular}{lccc|ccc|}
\hline Digestibility & \multicolumn{3}{c|}{ C:R ratio } & \multicolumn{3}{c|}{ RY supplementation } \\
\cline { 2 - 6 } coefficients\% & HC & HR & 士SE & + & - & $\mathbf{\pm S E}$ \\
\hline NDF & $48.32^{\mathrm{a}}$ & $44.45^{\mathrm{b}}$ & 0.35 & $47.80^{\mathrm{a}}$ & $44.97^{\mathrm{b}}$ & 0.35 \\
ADF & $34.40^{\mathrm{a}}$ & $30.88^{\mathrm{b}}$ & 0.35 & $34.02^{\mathrm{a}}$ & $31.27^{\mathrm{b}}$ & 0.35 \\
Hemicellulose & $60.88^{\mathrm{a}}$ & $55.33^{\mathrm{b}}$ & 0.34 & $60.48^{\mathrm{a}}$ & $55.73^{\mathrm{b}}$ & 0.34 \\
Cellulose & $43.95^{\mathrm{a}}$ & $39.17^{\mathrm{b}}$ & 0.38 & $43.23^{\mathrm{a}}$ & $39.88^{\mathrm{b}}$ & 0.38 \\
ADL & $21.95^{\mathrm{a}}$ & $18.85^{\mathrm{b}}$ & 0.36 & $21.35^{\mathrm{a}}$ & $19.27^{\mathrm{b}}$ & 0.36
\end{tabular}

HC :high CFM, HR: high CS,(+) with RYS, (-) without RYS

${ }^{a}$ and ${ }^{b}$ : means in the same row with different superscripts differ significantly $(P<0.05)$

The results in Table (3) showed that the digestibility coefficients of OM, $\mathrm{CP}, \mathrm{CF}, \mathrm{EE}$ and NFE were significantly higher $(\mathrm{P}<0.05)$ with $\mathrm{RY}$ supplemented (RYS) diet than unsupplemented one (USRY). The obtained results match with those of Paryad and Rashidi (2009), Mousa et al. (2012) and Mehrez et al. (2013) who found that lambs fed diets supplemented with RLY had higher nutrients digestibility than unsupplemented ones .

As shown in Table (4) the addition of Rumi yeast (Saccharomyces cerevisiae) to Zaraibi goats diets had significantly $(P<0.05)$ improved all fibel $r$ fractions digestibility. Similar results were reported by Gabr et al. (2004) and Abdelmawla et al. (2007). The improvement in fiber digestibility may also be due to stimulation of cellulolytic bacteria activity.
Formatted: Font: Not Bold, Complex Script Font: Not Bold

Formatted: Font: Not Bold, Complex Script Font: Not Bold
Formatted: Font: Not Bold, Complex Script Font: Not Bold Formatted: Font: Not Bold, Complex Script Font: Not Bold Formatted: Font: Not Bold, Complex Script Font: Not Bold

Formatted: Font: Not Bold, Complex Script Font: Not Bold Formatted: Font: Not Bold, Complex Script Font: Not Bold 
Regarding the effect of RYS on the feeding values of the tested diets, it was clear that the TDN\% was higher $(P<0.05)$ by about $2.28 \%$ with RYS diet than USRY one (Table 3). The DCP\% was significantly $(\mathrm{P}<0.05)$ enhanced by the addition of Rumi yeast culture. These results are in agreement with the those obtained by Komonna (2007) and Helal and Abdel-Rahman (2010) and Mehrez et al. (2013) who reported that the values of TDN and DCP\% were significantly $(\mathrm{P}<0.05)$ improved when supplementing diets with yeast culture and commercial probiotic.

In this respect, Willimas et al. (1991) indicated that a primary benefit of yeast culture is its ability to alter conditions detrimental to cellulolysis, suggesting that yeast culture has minimal influence on concentrate diet digestibility, but may alleviate negative associative effects between concentrates and forages.

\section{Effect of C:R ratio, RYS and sampling time on some rumen fluid} parameters:

The values of ruminal $\mathrm{pH}, \mathrm{NH}_{3}-\mathrm{N}$ and total volatile fatty acids (TVFA's) concentrations at zero, 3 and 6 hrs post-feeding are illustrated in Table (5) and Figs. 1,2 and 3 , respectively. Ruminal $\mathrm{pH}$ value is one of the most important factors, which affect microbial fermentation in the rumen and influence its functions. As shown in Table (5) and (Fig.1), ruminal pH values were significantly $(P<0.05)$ influenced by $R: C$ diet, RYS and sampling time. Generally, the highest values were recorded before feeding, while the lowest values were obtained at 3 hours post-feeding, then $\mathrm{pH}$ values tended to increase with time advancement. These results are in agreement with those reported by Abd El-Ghani (2004) who reported that addition of yeast culture (YC) to Zaraibi goats rations caused higher $(\mathrm{P}<0.05)$ ruminal $\mathrm{pH}$ at $3 \mathrm{hrs}$ post-feeding compared with the control ration. Similar results were obtained by Gabr et al. (2004) with sheep, Bacha et al. (2007) and Guedes et al. (2008) for dairy cows. Abd El-Ghani (2004), Guedes et al. (2008) and Mardiati et al. (2010) reported increases in ruminal $\mathrm{pH}$ related to low concentrations of lactic acid in the rumen because Sacharomyces cerevisiae can stimulate the growth of lactic acid bacteria. Such confliction in the results concerning the effect of RYS on ruminal $\mathrm{pH}$ could be due to many factors such as the level of YC supplementation (Ebrahim, 2004 and Abdel-Latif, 2005), variation in plans of nutrition, frequency of feeding, animal species and age_(Abdel-Khalek et al., 2000), roughage to concentrate ratio (Kholif and Khorshed , 2006), sampling time and different management conditions. These results are in agreement with those reported by Gabr et al. (2004) and Elmekass et al. (2007)t who concluded that as the proportion of CFM increased in the diets of ruminants, ruminal $\mathrm{pH}$ values tended to be decreased. This could be explained by the increasing readily available carbohydrates to be fermented in the rumen (Maklad and Mohamed, 2000)

Table 5. Mean effect of R: C ratio, RY supplementation and sampling times on some rumen liquor parameters of bucks fed the experimental diets.

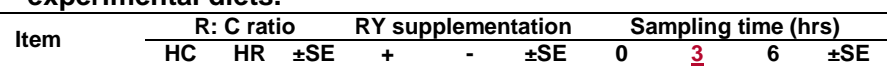

Formatted: Font: Not Bold, Complex Script Font: Not Bold

Formatted: Font: Not Bold, Complex Script Font: Not Bold

Formatted: Font: Not Bold, Complex Script Font: Not Bold

Formatted: Font: $10 \mathrm{pt}$, Complex Script Font: $10 \mathrm{pt}$, Lowered by 2 pt

Formatted: Font: Not Bold, Complex Script Font: Not Bold

Formatted: Font: Not Bold, Complex Script Font: Not Bold

Formatted: Font: Not Bold, Complex Script Font: Not Bold

Formatted: Font: Not Bold, Complex Script Font: Not Bold

Formatted: Font: Not Bold, Complex Script Font: Not Bold

Formatted: Font: Not Bold, Complex Script Font: Not Bold

Formatted: Font: Not Bold, Complex Script Font: Not Bold

Formatted: Font: Not Bold, Complex Script Font: Not Bold

Formatted: Font: Not Bold, Complex Script Font: Not Bold

Formatted: Font: Not Bold, Complex Script Font: Not Bold

Formatted: Font: Not Bold, Complex Script Font: Not Bold

Formatted: Font: Not Bold, Complex Script Font: Not Bold

Formatted: Font: Not Bold, Complex Script Font: Not Bold

Formatted: Font: Not Bold, Complex Script Font: Not Bold

Formatted: Font: Not Bold, Complex Script Font: Not Bold

Formatted: Font: Not Bold, Complex Script Font: Not Bold

Formatted: Font: Not Bold, Complex Script Font: Not Bold

Formatted: Font: Not Bold, Complex Script Font: Not Bold

Formatted: Font: Not Bold, Complex Script Font: Not Bold

Formatted: Font: $10 \mathrm{pt}$, Complex Script Font: $10 \mathrm{pt}$ 


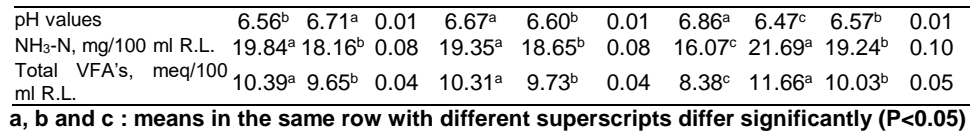

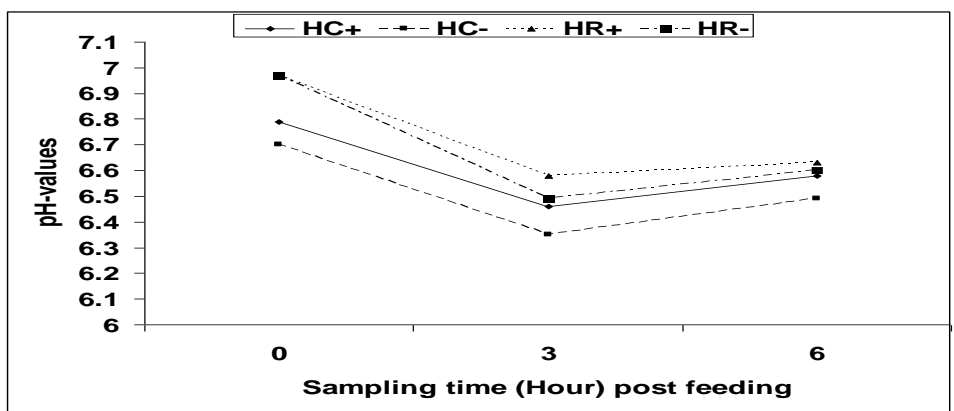

Fig (1): - Interaction of $R: C$ ratio, $R Y S$ and sampling time on ruminal $\mathrm{pH}$ values with bucks.

Data in Table (5) and Fig. (2) also illustrated that ruminal ammonia-N concentration of bucks were significantly $(P<0.05)$ affected by $R: C$ ratio, $R Y$ supplementation and sampling time. In general, $\mathrm{NH}_{3}-\mathrm{N}$ concentration was the highest $(19.84 \mathrm{mg} / 100 \mathrm{ml} \mathrm{RL}$ ) with bucks fed $\mathrm{HC}$ diet, while the lowest concentration $(18.16 \mathrm{mg} / 100 \mathrm{ml} \mathrm{RL})$ was recorded with those fed HR one.

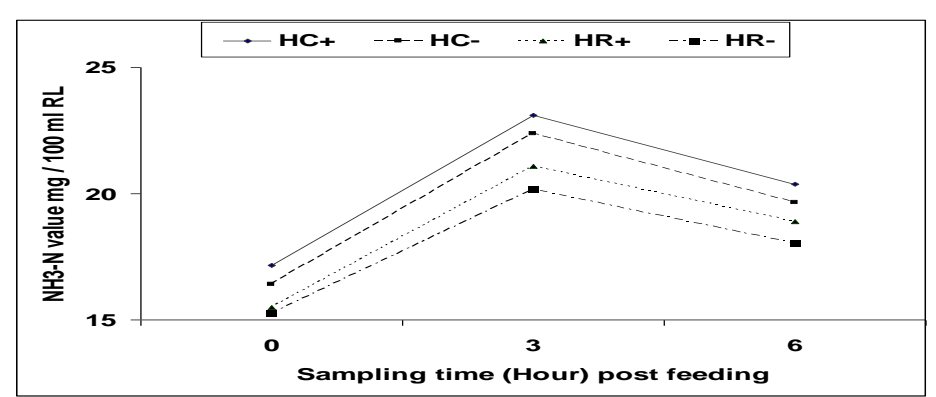

Fig (2): Interactionof R : C ratio, RYS and sampling time on ruminal $\mathrm{NH}_{3}-\mathrm{N}$ concentration with bucks.

Regarding the effect of sampling time, the lowest value was recorded before feeding $(16.07 \mathrm{mg} / 100 \mathrm{ml} \mathrm{RL})$, while, the highest $\mathrm{NH}_{3}-\mathrm{N}$ concentratio $(21.69 \mathrm{mg} / 100 \mathrm{ml} \mathrm{RL}$ ) was obtained at 3 hours post-feeding. These results are in agreement with those reported by Gabr et al. (2004), Elmekass et all. (2005) and Elmekass et al., (2007) who demonstrated that the assessment of
Formatted: Font: 10 pt, Complex Script Font: 10 pt, Lowered by 2 pt

Formatted: Font: Not Bold, Complex Script Font: Not Bold Formatted: Font: Not Bold, Complex Script Font: Not Bold 
optimal $\mathrm{NH}_{3}$ concentration for maximal rate of fermentation is considered extremely variable because of the diurnal variation associated with feeding time as well as dietary source and level of energy to be fermented in the rumen. It increases with increasing level of concentrate in the diet. The highest concentration (19.84 mg/100 ml RL) was noticed with bucks fed RYS compared to the bucks fed USRY diet $(18.16 \mathrm{mg} / 100 \mathrm{ml} \mathrm{RL})$. Similar results have beenwere reported by Dolezal et al. (2005) for Holstein dairy cows, Fadel Elseed and Abusamara (2007) with Nubian goat's kids. They reported that YC supplementation tended to have-cause greater ruminal ammonia concentrations than unsupplemented (USRY) groups. There are several factors influencing the ammonia concentration in the rumen (Dolezal et al. 2005 and Inal et al., 2010): firstly: the composition of animal diet; since diets containing a high proportion of concentrates (above $70 \%$ ) leads to lower protein synthesis in the rumen, while it increases the ammonia concentration. Secondly: the animal physical condition; animals with acute rumen acidosis, the ammonia concentration is increased (Dolezal et al., 2005). Finally: the rumen microbial population; when microbial population increases, the microbial ammonia incorporation increase so decrease ammonia production in the rumen (Chaucheyras-Durand et al., 2005, Moallem et al., 2009 and Mardiati et al., 2010).

Results in Table (5) and Fig. 3 , cleared that the average ruminal VFA's concentrations were significantly $(P<0.05)$ affected by $R: C$ ratio and sampling time. The VFA's concentration was the highest $(10.39 \mathrm{meq} / 100 \mathrm{ml} \mathrm{RL})$ with bucks fed HC diet, while the lowest concentration (9.65 meq/100 ml RL) was recorded with bucks fed HR diet. Similar results have been given by Gabr et al. (2004) who reported that feeding higher concentrate levels increased concentration of VFA's and decreased acetate level in sheep fed low roughage diet. In the present study, the $R Y$ addition had significant $(P<0.05)$ effect on ruminal total VFA concentration.

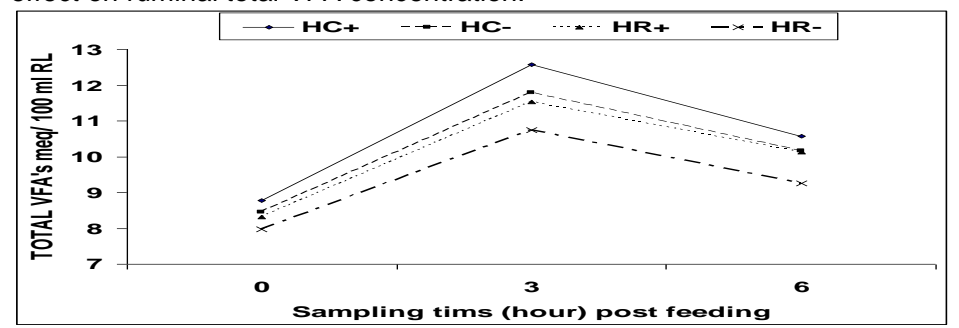

Fig (3): Interaction of R : C ratio, RYS and sampling time on ruminal TVA's concentration with bucks.

Regarding the effect of sampling time, the data in Table (5) revealed that VFA's concentration was low before feeding $(8.37 \mathrm{meq} / 100 \mathrm{ml} \mathrm{RL}$ on average), and peaked after 3 hours post-feeding (11.65 meq/100 ml RL). The increase in VFA concentration at 3 hours post-feeding could be associated with decrease in ruminal $\mathrm{pH}$ value (Table 5), since these two parameters are metabolically correlated. The results obtained herein came in line with those
Formatted: Lowered by $3 \mathrm{pt}$

Formatted: Font: Not Bold, Complex Script Font: Not Bold

Formatted: Font: Not Bold, Complex Script Font: Not Bold

Formatted: Font: Not Bold, Complex Script Font: Not Bold

Formatted: Font: Not Bold, Complex Script Font: Not Bold

Formatted: Font: Not Bold, Complex Script Font: Not Bold

Formatted: Font: Not Bold, Complex Script Font: Not Bold

Formatted: Font: Not Bold, Complex Script Font: Not Bold

Formatted: Font: Not Bold, Complex Script Font: Not Bold

Formatted: Font: Not Bold, Complex Script Font: Not Bold

Formatted: Font: Not Bold, Complex Script Font: Not Bold 
obtained by Abd El-Ghani (2004), Bagheri et al. (2009) and Mardiati et al. (2010). In general, they found that rumi yeast culture supplementation had significantly increased ruminal $\mathrm{pH}$, ruminal $\mathrm{NH}_{3}-\mathrm{N}$ concentration and ruminal total VFA concentration. However, there are many factors that could influenced by yeast supplementation and affect the VFA concentration in the rumen being the qualitative and quantitiave-composition of the diet (Dolezal et al., 2005), activities of microbes in the rumen since S.Cerevisiae produces growth factors for microbial growth in the form of organic acids, vitamin B and amino acids that can stimulate rumen microbial growth and activity, as well as (Mardiati et al., 2010), differences between animals and saliva that affects these values (Abd El-Ghani, 2004) and DM digestibility, rate of absorption, rumen $\mathrm{pH}$, transportation of the digesta from the rumen to other parts of the digestive tract and the microbial population in the rumen and their activities (Allam et al., 2006).

\section{CONCLUSSION}

It could be concluded that addition of Rumi yeast $(R Y)$ at $3 \mathrm{~g} / \mathrm{d} / \mathrm{h}$ to Zaraibi bucks diets was proven to be effective in terms of beneficial effects on digestibility coefficients, feeding value and on ruminal microbial activities and fermentation stability and has higher influence when included with high concentrate diet than high roughage - based diet.

\section{REFERENCES}

A.O.A.C. (1995). Official Methods of Analysis. $15^{\text {th }}$ ed. Association of Official Analytical Chemists. Arlington, Virginia, USA.

Abd El-Ghani, A.A. (2004). Influence of diet supplementation with yeast culture (Sacharomyces cerevisiae) on performance of Zaraibi Goats. Small Ruminant Res., 52.

Abdel-Khalek, A. E.; Mehrez, A. F. and Omar, E. A. (2000). Effect of yeast culture (Lacto-Sacc) on rumen activity, blood constituents and growth of suckling Friesian calves. Prod. Conf. Anim. Prod. In the $21^{\text {th }}$ Century, Sakha, $18-20$ April : 201.

Abdel-Latif, M.A.(2005). Physiological and nutritional studies on reproduction in diary cattle. Ph.D. Thesis, Fac. Agric., Mansoura Univ.

Abdelmawla, S. M.; El-Sherbiny, A. M.; El-Medany, N. M. and Salem, F. A. (2007). Productive performance, nutrient digestibility, some blood constituents and carcass traits of growing rabbits fed diets containing probiotics. The 1st Inter. Con. on Rabbit Prod. In Hot Clim. Hurghada, Egypt, 191.

Abou Ammou, Faten. F.; El-Badawi, A.Y.; Abdel-Kalek, T.M.M.; Hafez, Y.H.; Mahrous, A.A. and El-Shafie, M.H. (2011). Nutritional evaluation of a new fungal-yeast probiotic fortified with natural antioxidants on performance of lambs, body weight gain, feed conversion efficiency, local breeds of sheep raised under two different climatic conditions. Egyptian J. Nutrition and Feeds, 14 (3): 379.
Formatted: Font: Not Bold, Complex Script Font: Not Bold

Formatted: Font: $10 \mathrm{pt}$, Complex Script Font: $10 \mathrm{pt}$, Lowered by 2 pt

Formatted: Font: Not Bold, Complex Script Font: Not Bold

Formatted: Font: Not Bold, Complex Script Font: Not Bold

Formatted: Font: Not Bold, Complex Script Font: Not Bold

Formatted: Font: Not Bold, Complex Script Font: Not Bold

Formatted: Font: Not Bold, Complex Script Font: Not Bold

Formatted: Font: Not Bold, Complex Script Font: Not Bold

Formatted: Font: 10 pt, Not Bold, Complex Script Font: 10 pt, Not Bold 
Abou-Akkada, A. R. and El-Shazly, K. (1964). Effect of absence of ciliate protozoa from the rumen on microbial activity and growth of lambs. Appl. Microbiol, 12: 384.

Aboul-Fotouh, G.E; Allam, S.M.; El-Gaafarawy, A.M.; El-Zelaky, O.A. and Abdel-Hafeez. (2011). Productive and reproductive performance of dairy cows fed corn silage without or with some microbial additives. Egyptian J. Nutrition and Feeds, 14 (3): 393.

Al-Dabeeb, S.N. and Ahmed, B.M. (2002). Effect of dry yeast (Saccharomyces cerevisiae) in sheep rations differing in their roughage to concentrate retio on digestion, nitrogen balance and rumen fermentation. Egyptian J. Nutrition.-and Fedds, 5:1.

Allam, S. M.; Al-Bedawi, T. M.; El-Amary, Hanaa H. and Mohamed, Shreen, H. (2006). Improving sugar beet pulp through biological treatment and its use in sheep rations. Egyptian J. Nutrition and Feeds, 9(2):235.

Bacha, A.; Iglesias, C. and Devant, M. (2007). Daily rumen pH pattern of loose-housed dairy cattle as affected by feeding pattern and live yeast supplementation. Animal Feed Science and Technology 2 136: 146.

Bagheri, M.; Ghorbain, G.R.; Rahmani, H.R.; Khorvash, M.; Nili, N. and Sudekum, K.H. (2009). Effect of live yeast and mannanoligosaccharides on performance of early-lactation Holstein dairy cows. J. Animal Sci., 22: 812-818.

Chaucheyras-Durand, F.; Masseglia, S. and Fonty, G. (2005). Effect of the microbial feed additive Saccharomyces cerevisiae CNCM I-1077 on protein and peptide degrading activities of rumen bacteria grown in vitro. Curr. Microbiol., 50: 96.

Chaucheyras-Durand, F.; Walker, N.D. and Bach, A. (2008). Effects of active dry yeasts on the rumen microbial ecosystem: past, present and future. Anim. Feed Sci. and Technol., 145: 5.

Conway, E.J. and O'Malley (1957). Micro diffusion methods. Ammonia and urea using buffered absorbents. Biochem. J., 36:655.

Dolezal, P.; Dolezal, J. and Trinacty, J. (2005). The effect of Saccharomyces cerevisiae on ruminal fermentation in dairy cows. Czech J. Anim. Sci., 50(11): 503.

Duncan, D.B. (1955). Multiple Range and Multiple F-test. Biomertrics, 11: 1.Egypt J. of Appl. Sci., (11) 1.

Ebrahim, S. E. A. (2004). Physio-nutritional studies on Egyptian buffaloes. Ph. D. Thesis, Fac. Agric. Mansoura Univ.

El-Ashry, M.A., Abou-Selim, I.A.; El-Sayed, H.M. and El-Aidy, A.A. (2003). Effect of maize silage with berseem on productive performance of dairy buffaloes. Egyptian J. Nutrition and Feeds, 6 (1):25.

El-Badawi, A.Y.; Abou Ammou, Faten. F.; Mahrous, A.A.; El-Shafie, M.H.; Abdel-Kalek, T.M.M and Hafez, Y.H. (2011). Nutritional evaluation of a fungal-yeast probiotic fortified with natural antioxidants on performance of sheep, nutrients digestibilities, dietary nitrogen utilization, rumen fermentation and changes of blood biochemical constituents. Egyptian J. Nutrition and Feeds, 14 (3): 367.
Formatted: After: $-0.06 \mathrm{~cm}$

Formatted: Font: (Default) Arial, Font color: Auto, Complex Script Font: Arial 
Elmekass, A. A. M. and Safaa N. Abd El-Azeem, Safaa N.(2007). Effect $\phi f$ source and level of energy and yeast addition on lambs performance. Egyptian Journal of Applied Science, 22 (1): 1.

Elmekass, A. A.M.; Shakweer, I.M.E.; Safaa Abd El-Azeem, Safaa N. and Shehata, E.I. (2005). Effect of yeast supplementation and different types of roughage on roughage-on growing lambs performance. Aninh. Prod. Res. Inst., Sakha. 137.

Fadel Elseed, A.M.A and Abusamra, R.M.A. (2007). Effects of supplemental yeast (Saccharomyces cerevisiae) culture on NDF digestibility and rumen fermentation of forage sorghum hay in Nubian goat's kids. Journal of Agriculture and Biological Sciences, 3: 133.

Fouad, R.T. (2001). A comparative study on the performance of Baladi cow calves and buffalo calves fed different levels of concentrates. J. Agric. Sci. Mansoura Univ., 26: 7607

Gabr A.A., Mehrez, A.Z.; EL-Ayek, M.Y.; Moustafa, M.R.M. and Hamed, E.Kh . (2004). Influence of dry yeast culture (lacture) supplementation to sheep diets differing in concentrate : roughage ratio on nutrient digestibilities, feeding values and some rumen parameters. 7 th Med. Zag. Conference ( 21-23 July).

Guedes, C.M.; Gonçalves, D.; Rodrigues, M.A.M. and Dias-da-Silva, A. (2008). Effects of a Saccharomyces cerevisiae yeast on ruminal fermentation and fibre degradation of maize silages in cows. Animal Feed Science and Technology, 145: 27.

Haddad, S.G. and Goussous, S.N. (2005a). Effect of yeast culture supplementation on nutrient intake, digestibility and growth performance of Awassi lambs. Anim. Feed Sci. and Technol., 118: 343.

Haddad, S.G. and Goussous, S.N. (2005b). Effect of yeast culture supplementation on nutrient intake and rumen fermentation of forage sorghum hay in Nubian goat's kids. J. Agric. and Biol. Sci., 3: 133.

Helal, F.I.S. and Abdel- Rahman, K.A. (2010). Productive performance of lactating ewes fed diets supplementing with dry yeast and/or bentonite as feed additives. World J._Agric. Sci. ${ }_{2}$ 6(5):489.

Inal, F. ; Gürbüz, E. ; Coşkun, B. ; Alataş, M.S. ; Çitil, Ö.B. ; Polat, E.S. Şeker, E. and Özcan, C. (2010). The effects of live yeast culture (saccharomyces cerevisiae) on rumen fermentation and nutrient degradability in yearling lambs. Kafkas Univ Vet Fak Derg., 16 (5): 799.

Kholif, S. M. and Khorshed, M. M. (2006). Effect of yeast or selenized yeast supplementation to rations on the productive performance of lactating buffaloes. Egyptian J. Nutr. and Feeds, 9 (2) : 193.

Kim, H.S.; Ahn, B.S.; Chung, S.G.; Moon, Y.H.; Ha, J.K.; Seo, I.J.; Ahn, B.H. and Lee, S.S. (2006). Effect of yeast culture, fungal fermentation extract and nonionic surfactant on performance of Holstein cows during transition period. Anim. Feed Sci. Technol., 126: 23.

Komonna,O.F.A. (2007). Phsiological and nutritional responses of sheep to some feed additives. Ph.D. Thesis, Fac. Agric., Minufiya University.

Lila, Z.A.; Mohammed, N.; Yasui, T.; Kurokawa, Y.; Kanda, S. And Itabashi,H. (2004). Effects of twin strain of Saccharomyces cerevisiae live cells on 


\section{Mehrez, A.Z. et al.}

mixed ruminal microorganism fermentation in vitro. J. Anim. Sci., 82: 1847.

MAFF (1975). Ministry of Agriculture, Fisheries and Food. Energy allowances and feeding systems for ruminants. Technical Bulletin, 33:, London, $\mathrm{H}$ M50.

Maklad, E. H.M. and Mohamed, B.K. (2000). Comparison among the effect of clover hay and corn silage as feed ingredients on the nutritive value, bacteria strains and fermentation in the rumen of sheep. $3^{\text {rd }}$ All Africa Conf. on Anim. Agric. And $11^{\text {th }}$ conf of Egypt. Soc. of Anim. Prod., Alexandria, Egypt, 6-9 November.

Mardiati, Z.; Arnim, R. W.; S. Ningrat, S. and R. Herawati, R. (2010). Effect of yeast (Saccharomyces Gerevisiaecerevisiae) on fermentability, microbial population and digestibility low quality roughage (in vitro). Archiva Zootechnica, 14:(4), 51

Maseki, T.; Mikulec, Z.; Valpotic, H.; Antunac, N.; Mikulec, N.; Stojevic, Z.; Filipovic, N. and Pahovic, S. (2008). Influence of live yeast culture (Saccharomyces cerevisiae) on milk production and composition, and blood biochemistry of grazing dairy ewes during the milking period. Acta Vet. Brno., 77: 547.

Mehrez, A.Z.; Gabr, A.A.; Mahrous, A.A.; Zelaky, O.A. and Fayed, Amal M.A. (2013). Influence of live yeast feed additives on productive performance of growing rahmany lambs. J. Agric. Sci. Mansoura Univ., 4: 233-247.

Mehrez, A.Z.; Soliman, E.M., El-Ayek, M.Y.; El-Ayouty, E.A. and El-Kholany, M.E. (2001). Influence of roughage to concentrate ratio and type of roughage on digestibility, some rumen parameters and fiber fractions digestibility of tested rations with ruminants. Egyptian J. Nutr. and Feeds., 4(Special Issue): 193.

Miller, T. W.; Hover, W.H.; Holt, M. and Nocek, J.E. (2002). Influence of yeast culture on ruminal microbial metabolism in continuous culture. J. Dairy Sci., 85: 2009.

Moallem. U.; Lehrer. H.; Livshitz. L.; Zachut. M. and Yakoby, S. (2009). The effects of live yeast supplementation to dairy cows during the hot season on production, feed efficiency, and digestibility. J. Dairy Sci., 92: 343-51.

Mousa, Kh.M.; El-Malky, O. M.; Komonna, O.F. and Rashwan,S. E. (2012). Effect of some yeast and minerals on the productive and reproductive performance in ruminants. Journal of American Science, 8(2): 291.

NRC, National Research Council (1981). Nutrient Requirements of Goats. Nat. Res. Council.

Nursoy, H. and Baytok, E. (2003). The effects of baker's yeast (Saccharomyces cerevisiae) in dairy cow diets on milk yield, some rumen. uid parameters and blood metabolites of dairy cow diets. Turk Veterinerlik ve Hayvanclk Dergisi, 27:7.

Paryad, A. and Rashidi,M. (2009). Effect of yeast (Saccharomyces cerevisiae) on apparent digestibility and productive performance of lactating buffaloes. Egyptian J. Nutr. and Feeds, 9 (2) : 193. 
SAS. Institute (2004). SAS User's Guide: Statistics Version, Fifth Edition. SAS. Institute Inc., Cary NC., USA.

Van Keulen, J. and Young, B.A. (1977). Evaluation of acid-isoluble ash as la natural marker in ruminant digestion studies. J. Anim. Sci., 44:282.

Van Soest, P.J. (1981). Limiting factors in plant residues of low biodegradability. Agric. Environment, 6:135.

Williams, P. E. V.; Tait, C.A. G.; Innes, G.M. and Newbold, C. J. Newbold (1991). Effects of the inclusion of yeast culture (Saccharomyces cerevisiae plus growth medium) in the diet of dairy cows on milk yield and forage degradation and fermentation patterns in the rumen of steers. J. Anim. Sci. 69:3016.

Yalçın, S.; Can, P.O.; Gürdal, A.; Bağcı, C. and Eltan, Ö. (2011). The nutritive value of live yeast culture (Saccharomyces cerevisiae) and its effect on milk yield, milk composition and some blood parameters of dairy cows. Asian-Aust. J. Anim. Sci. ${ }_{2}$ 24: 1377.

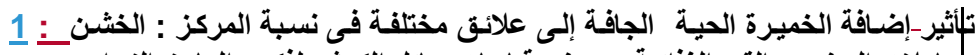

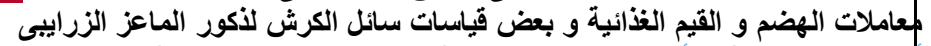

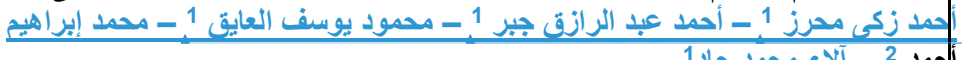

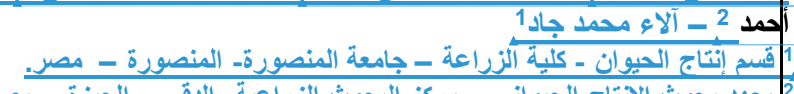

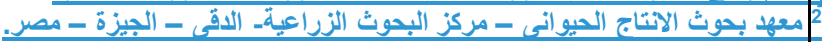

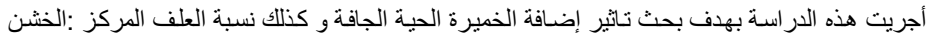

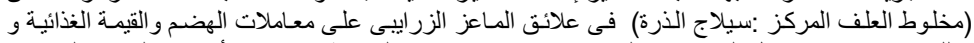

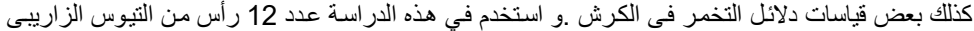

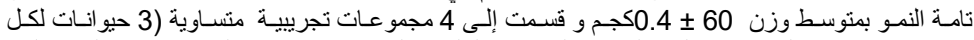

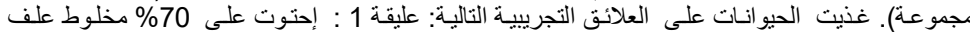

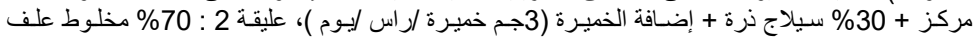

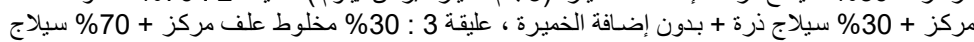

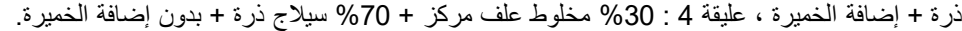

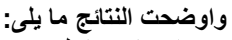

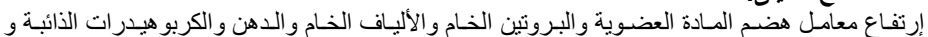

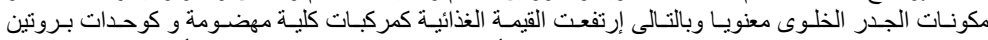

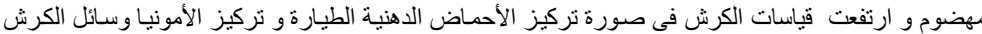

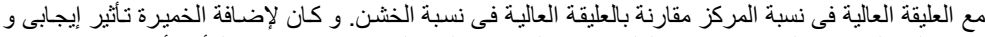

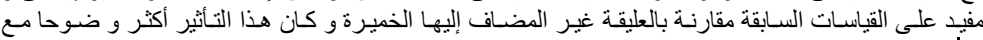

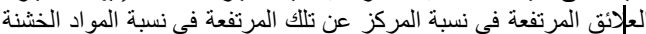

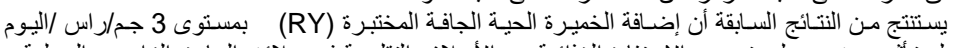

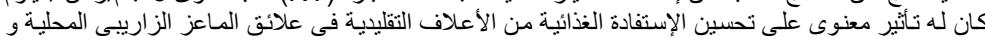

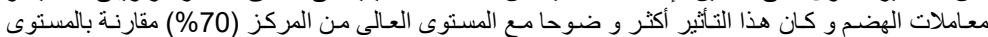
العلى من سيلاج الذرة (70\%)
كلية الزراعة - جامعة المنصورة مركز البحوث الزراعية
قام بتحكيم البحث

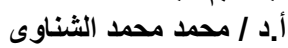

أ. أد / محمد حلمى ياقوت أدماوت
347
Formatted: Font color: Auto, Complex Script Font: Arabic Transparent, (Complex) Arabic (Saudi Arabia), Superscript

Formatted: Font color: Auto, Complex Script Font: Arabic Transparent, (Complex) Arabic (Saudi Arabia), Superscript

Formatted: Font color: Auto, Complex Script Font: Arabic Transparent, (Complex) Arabic (Saudi Arabia), Superscript

Formatted: Font color: Auto, Complex Script Font: Arabic Transparent, (Complex) Arabic (Saudi Arabia), Superscript

Formatted: Font color: Auto, Complex Script Font: Arabic Transparent, (Complex) Arabic (Saudi Arabia), Superscript

Formatted: Font: (Default) Arial, 11 pt, Font color: Auto, Complex Script Font: Arabic Transparent, 11 pt, Superscript 
Mehrez, A.Z. et al. 